\title{
AGROBACTERIUM-MEDIATED TRANSFORMATION OF PANAX VIETNAMENSIS HA ET GRUSHV.
}

Duong Tan Nhut ${ }^{1,}$, Nguyen Phuc Huy ${ }^{1}$, Trinh Thi Huong ${ }^{1,2}$, Vu Quoc Luan ${ }^{1}$, Vu Thi Hien ${ }^{1}$, Hoang Thanh Tung', Do Manh Cuong ${ }^{1}$, Chu Thi Bich Phuong ${ }^{1}$, Pham Bich Ngoc ${ }^{3}$, Nguyen Dinh Trong ${ }^{3}$, Nguyen Khac Hung ${ }^{3}$, Chu Hoang $\mathrm{Ha}^{3}$

${ }^{1}$ Tay Nguyen Institute for Scientific Research, Vietnam Academy of Science and Technology

${ }^{2}$ Ho Chi Minh City University of Food Industry

${ }^{3}$ Institute of Biotechnology, Vietnam Academy of Science and Technology

To whom correspondence should be addressed. E-mail: duongtannhut@gmail.com

Received: 27.11 .2017

Accepted: 28.12.2017

\section{SUMMARY}

In recent years, the Agrobacterium-mediated genetic transformation system has become the most useful method widely used for the introduction of foreign genes into plant cells followed by regeneration of genetically improved plants. Panax vietnamensis Ha et Grushv. is a highly valued medicinal plant native to Vietnam with limited area of distribution. This report illustrates the possibilities of biotechnology for genetic transformation aimed at establishing an effective production of secondary metabolites in P. vietnamensis. In the present investigation, $0.5 \mathrm{~cm}^{2}$ leaf blades, $1 \mathrm{~cm}$ long leaf petioles and $0.5 \mathrm{~cm}^{3}$ callus clusters were used for the hairy root induction. Results indicated that hairy roots were induced on P. vietnamensis callus clusters cocultivated with Agrobacterium rhizogenes strain ATCC15834 at $\mathrm{OD}_{600}$ of 0.5 with an infection time of 20 min and a supplementation of $100 \mu \mathrm{M}$ acetosyringone. PCR amplification of the DNA isolated from the resulting hairy roots was used to confirm the presence of rol genes. Compared to in vitro rhizome cultures, hairy root cultures appear to be potential for continuous production of valuable secondary metabolites with similar saponin profiles. The protocol described in this study is simple and rapid and therefore, can be used for largescale experiments for the rapid production of valuable compounds.

Keywords: Agrobacterium rhizogenes, gene transformation, hairy roots, Panax vietnamensis Ha et Grushv., saponins

\section{INTRODUCTION}

Panax vietnamensis Ha et Grushv., a precious medicinal plant, mainly grows on high mountain of Ngoc Linh (Kontum and Quang Nam provinces) at an altitude of about $1,800 \mathrm{~m}$. It was a secret medicinal plant of the Sedang ethnic group and used for the treatment of many serious diseases and enhancing body strength during long journeys on high mountains. According to numerous studies, $P$. vietnamensis has several medical effects such as anti-depressant, anti-aging, anti-cancer activities, memory improvement, liver protection, immune system stimulation, etc. (Nhut et al., 2012). A study that examined the chemical constituents in $P$. vietnamensis roots revealed that it contains up to 50 saponins. Moreover, P. vietnamensis accumulates saponins at higher levels compared to other species such as $P$. ginseng, $P$. quinquefolium, $P$. notoginseng (Duc et al., 1994).

$P$. vietnamensis takes long time to grow, and its ginsenoside level sufficiently accumulates until it reaches four to six years of age. At present, due to the limited supply of natural population, slow growth, and excessively harvesting, this ginseng is listed as one of the endangered species, at high risk of extinction in Vietnam (Vietnam' Red Data Book).

Genetic transformation is one the most widely used method for increasing the production of secondary metabolites in plants. Transformation using Agrobacterium rhizogenes of some economically important species to obtain transformed hairy roots have been reported. Since 
the intact transformed plants are capable of synthesizing a large quantity of biologically active substances, the potential to metabolically engineer plants to significantly increase the production of these metabolites could be achieved (Georgiev et al., 2007; Guillon et al., 2006).

A. rhizogenes strains are the most frequently exploited gene transfer agents in a wide variety of plant species (Hooykaas, 1992). A. rhizogenes, a gram-negative soil bacterium, transfers DNA from its root inducing (Ri) plasmid into the genome of the infected plant (Chilton et al., 1982). Hairy roots induced by Ri plasmid have many advantages over normal roots, as they exhibit a vigorous growth and extensive lateral branching while growing in a simple phytohormone-free medium. The rolC gene of $A$. rhizogenes T-DNA plays an essential role in hairy root development and its expression in plants causes significant morphological and biochemical changes (Nilsson et al., 1996). Over the years, transformed root cultures from plants have received considerable attention because of their rapid growth rate, biochemical and genetic stability, ease of maintenance and ability to synthesize secondary metabolites (Shanks, Morgan 1999; Giri et al., 2001).

In this study, hairy roots were initiated from $P$. vietnamensis explants using $A$. rhizogenes strain ATCC15834. This is the first report on the development and optimization of an efficient transformation procedure for the establishment of transgenic $P$. vietnamensis root cultures using $A$. rhizogenes.

\section{MATERIALS AND METHODS}

\section{Plant materials}

Leaf blades (cut into $0.5 \mathrm{~cm}^{2}$ segments), leaf petioles (cut into $1 \mathrm{~cm}$ long) and callus clusters (cut into $0.5 \mathrm{~cm}^{3}$ blocks) of 3-month old in vitro plants, cultured on 1/2 Murashige and Skoog (MS; 1962) medium containing $1.0 \mathrm{mg} / 1 \mathrm{BA}, 0.5 \mathrm{mg} / 1 \mathrm{NAA}, 50$ $\mathrm{g} / 1$ sucrose and $2.0 \mathrm{~g} / 1 \mathrm{AC}$ (Nhut et al., 2013), were used for the hairy root induction.

\section{Bacterial strains and plasmids}

Wild-type strain of $A$. rhizogenes harboring the vector PTN289-GUS and $A$. rhizogenes strain ATCC15834 (obtained from Institute of Pharmacy and Molecular Biotechnology, Heidelberg
University, Germany) was used for the hairy root induction.

\section{Agrobacterium activation}

Bacterial culture was maintained in Yeast Mannitol Broth (YMB) solid medium supplemented with $100 \mathrm{mg} / 1$ spectinomycine at $28^{\circ} \mathrm{C}$ for 48 hours. A single bacterial colony was inoculated in $5 \mathrm{ml}$ of YMB liquid medium supplemented with $100 \mathrm{mg} / \mathrm{l}$ spectinomycine and the culture was grown on a rotary shaker at $220 \mathrm{rpm}$ at $28^{\circ} \mathrm{C}$ for $16-18$ hours. Subsequently, $45 \mathrm{ml}$ of YMB liquid medium was added to the overnight bacterial culture and grown at $28^{\circ} \mathrm{C}$ for about $4-6$ hours until it reached mid-log phase $\left(\mathrm{OD}_{600}=0.5\right)$. The bacterial cells were harvested by centrifugation and re-suspended at a cell density $\mathrm{OD}_{600}$ of 1.0 in $1 / 2 \mathrm{SH}$ medium (Schenk, Hildebrandt, 1972).

Transformation procedure: (Four investigations for infection were tested)

(1) Explants were sliced into $0.5 \mathrm{~cm}^{2}$ segments for leaf blades, $1 \mathrm{~cm}$ long for leaf petioles and 0.5 $\mathrm{cm}^{3}$ blocks for callus clusters in $1 / 2 \mathrm{SH}$ liquid medium. Explants were dried on sterile filter papers and transferred onto a new plate containing $30 \mathrm{ml}$ of overnight Agrobacterium suspension and incubated for $20 \mathrm{~min}$ with gentle shaking. The bacterial solution was discarded and the explants were dried on sterile filter paper and placed on $\mathrm{SH}$ solid medium for $2-3$ days under low light intensity (specify the specific flux rate $35-40 \mu \mathrm{mol} \mathrm{m} \mathrm{m}^{-2}$ ). After three days of inoculation with bacteria, the explants were placed onto new SH plates containing $500 \mathrm{mg} / \mathrm{l}$ cefotaxime. The explants were subcultured on new SH antibiotic plates every two weeks until hairy root tips appeared. Hairy root tips $(4-5 \mathrm{~cm})$ were then transferred to $50 \mathrm{ml}$ flasks containing 10 $\mathrm{ml}$ of SH liquid medium and placed on a shaker at 60 rpm and $22 \pm 2{ }^{\circ} \mathrm{C}$ for further analysis.

The selected explant type, which was the most suitable for gene transformation, was used for subsequent experiments.

(2) Explants were infected with Agrobacterium suspension of varying $\operatorname{OD}_{600}(0,0.3,0.5,0.7,0.9)$ in order to investigate the effect of bacterial density on transformation efficiency.

(3) Explants were also submerged in the Agrobacterium suspension for different time durations (10, 20 and $30 \mathrm{~min})$ in order to investigate 
the optimal infection time for transformation process.

(4) Different concentrations of acetosyringone (50, 100, 150 and $200 \mu \mathrm{M})$ were added to the infection medium to determine its effect on transformation efficiency.

The percentage of gus-positive explants was prepared according to the procedure described by Jefferson (1987). Samples were immediately submerged in gus staining solution after harvest and placed under a vacuum for $10 \mathrm{~min}$. The samples were incubated for 8-12 hours in darkness at $37^{\circ} \mathrm{C}$. Chlorophyll was removed by submerging the stained tissues in $70 \%(\mathrm{v} / \mathrm{v})$ ethanol. Plant material was placed on glass slides using $20 \%$ chloral $(\mathrm{w} / \mathrm{v})$ in $25 \%$ glycerol (v/v) for $10 \mathrm{~min}$. Gus staining was visualized using a Leica MZ95 stereomicroscope with a color CCD camera. The gus staining solution contained $100 \mathrm{mM}$ sodium phosphate buffer $(\mathrm{pH}$ 7.0), $10 \mathrm{mM} \mathrm{Na}_{2}$ EDTA, $\left.1 \mathrm{mM} \mathrm{K} 3 \mathrm{Fe}_{3}\left(\mathrm{CN}_{6}\right)\right], 1 \mathrm{mM}$ $\mathrm{K}_{4}\left[\mathrm{Fe}\left(\mathrm{CN}_{6}\right)\right], 0.5 \%(\mathrm{v} / \mathrm{v})$ TritonX-100, 20\% (v/v) methanol, and $0.5 \mathrm{mg} / \mathrm{ml}$ 5-bromo-4-chloro-3indolyl- $\beta$-d-glucuronic acid (X-gluc).

All experiments were repeated 3 times with 15 explants for each explants type and the mean values are presented.

\section{PCR analyses of transformation}

To confirm the transformation of hairy root clones, genomic DNA from hairy roots was isolated according to method described by Khanuja et al. (1999). PCR analyses were used to evaluate transformed roots using rolC-specific primers $\left(5^{\prime}\right.$ ATGGCTGAAGACGACCTGTGTT $3^{\prime}$ and $5^{\prime}$ TTAGCCGATTGCAAACTTGCAC 3'). The cycling conditions were denaturation at $94^{\circ} \mathrm{C}$ for 1 min, annealing at $53^{\circ} \mathrm{C}$ for $30 \mathrm{sec}$ and extension at $72^{\circ} \mathrm{C}$ for $1 \mathrm{~min}$, with samples being subjected to 30 cycles. The PCR products were analyzed on $1 \%$ $(\mathrm{w} / \mathrm{v})$ agarose gel stained with ethidium bromide $(0.5$ $\mu \mathrm{g} / \mathrm{ml})$.

\section{Evaluating transcript level of genes in ginseng hairy root transformants}

RNA was isolated from 28-day-old hairy root cultures using Trizol according to the manufacturer's protocol and cleaned up using the RNeasy Mini kit and optional on-column DNase digestion with the RNase-free DNase set from Qiagen. RNA quality and quantity were verified by NanoPhotometer. First-strand cDNA was synthesized from $1 \mu \mathrm{g}$ total
RNA using the ImProm-II ${ }^{\mathrm{TM}}$ Reverse Transcription System according to the supplier's instructions. The relative level of auxin transcripts of the transformants was further quantified by real-time RT-PCR using actin as a housekeeping gene. The relative expression of auxin genes was established using REST software. Primers used were rolB.F:5' GGAGGATGATAGCAGACTTTGTTCTTC 3'; rolB.R: 5, CAGCATGGAGCCAGATAAA CCTATT 3' for rolB gene and actin.F: 3' GATGACATGGAAAAGATTTGGCAT 5', actin.R: 3' TGTTGTACGACCACTAGCATACAGG 5' for actin gene.

\section{Saponin analysis}

$P$. vietnamensis in vitro transformed hairy roots were used for saponin analysis. The procedures for saponin extraction, HPLC analysis were described by Zhai et al. (2001).

HPLC system: Supelco RP C18 column (250 $\mathrm{mm} \times 4.6 \mathrm{~mm}$; I.D. $5 \mathrm{~mm}$ ), SPD-M20A-PDA detector. HPLC parameters: Volume injection of 20 $\mathrm{ml}$; flow rate: $0.5 \mathrm{ml} / \mathrm{min}$. Column temperature was held at $25^{\circ} \mathrm{C}$.

Sample $(0.5 \mathrm{~g})$ was exhaustively extracted in methanol in sonicator $(10 \mathrm{ml}$ methanol $\times 6$ times $)$. The extracts were pooled together and concentrated by evaporator to give dried residues, dissolved the residues with $20 \mathrm{ml}$ water and fractionated with ether ethylic and n-butanol, respectively. The ether ethylic fraction was discarded, and the n-butanol was collected and evaporated under vacuum pressure to yield the dried extract. The resulting dried extract was continuously dissolved with mixture of acetonitrile:water solvent $(2: 1, \mathrm{v} / \mathrm{v})$ and fixed in 5 $\mathrm{ml}$, passed through $0.45 \mu \mathrm{m}$ membrane, the filtrate was finally injected to HPLC system for quantitative determination of saponins by using calibration curve method.

\section{RESULTS AND DISCUSSION}

\section{Effect of explant types on gene transformation efficiency}

When performing transformation and regeneration experiments, explant selection is a critical parameter because the different explant sources often have varying potential for transformation (Piqueras et al., 2010). In the present study, it can be seen that different explant types 
resulted in different transformation efficiency (Fig. 1, Fig. 2). It was observed that callus produced the highest level of gus expression (86\%) among the three explant types examined. Britton et al. (2008) demonstrated that $\mathrm{rolB}$ is one of the most important genes contributing to hairy root induction and the phenotypes of hairy root are affected by auxin. Therefore, when we used callus as the explant material for gene transformation, there was an accumulation of auxin in callus clusters, and the hairy root induction ability from callus (Fig. 2c) was significantly higher than those from leaf blades or petioles.

In 1997, Giri et al. published a paper in which among $A$. rhizogenes strains used, A. rhizogenes LBA
9402 and A4 treated on callus resulted in the greatest hairy root induction in Aconitum heterophyllum whereas leaf, stem and other explant sources were found to be unsuitable for gene transformation. Several studies have also reported the differential efficiency of various $A$. rhizogenes strains in promoting the formation and growth of hairy roots (Ionkova et al., 1997; Vanhala et al., 1995). A. rhizogenes strain 15834 was among the most effective at promoting hairy root growth and saponin synthesis. In the current study, A. rhizogenes strain 15834 used in experiments is not included in the list of biologically active agents and is not considered biological hazard, hence, obtained genetically modified organism is not harmful, and callus was used as the plant material for subsequent experiments.

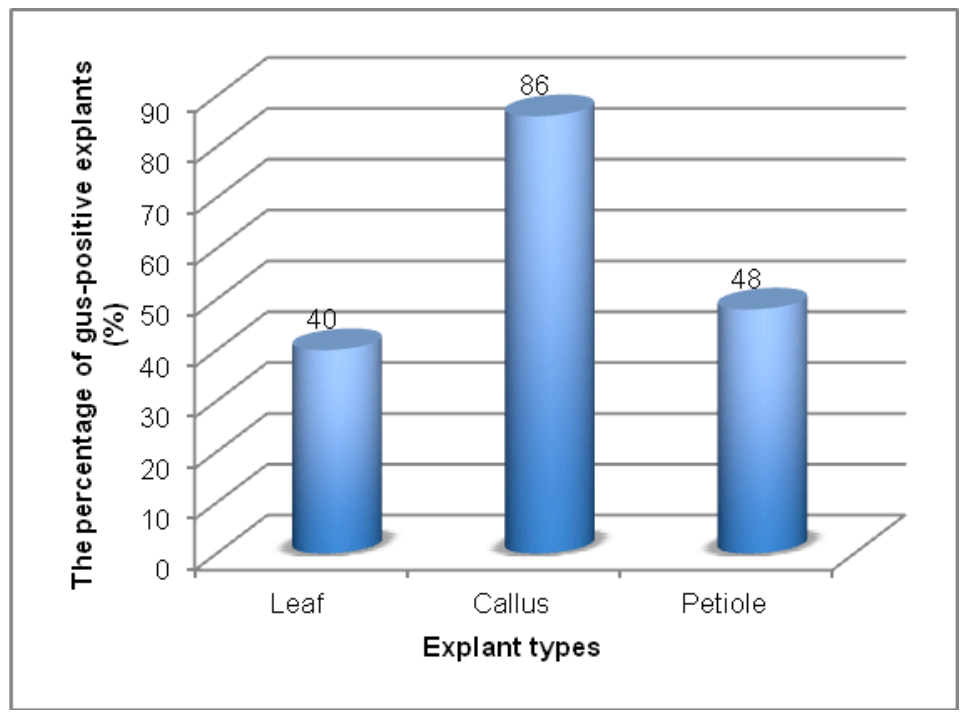

Figure 1. Effect of explant types on gene transformation efficiency.

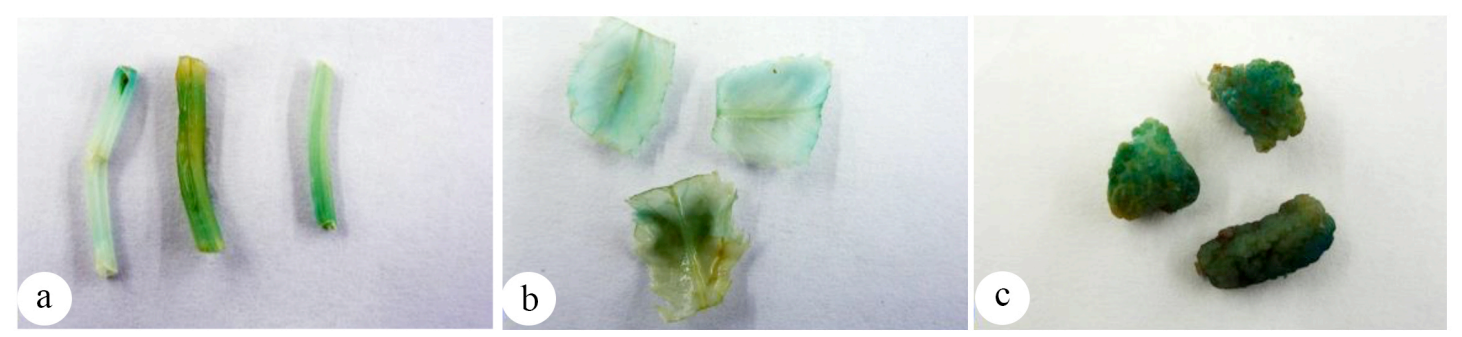

Figure 2. Gus expression in various $P$. vietnamensis explants following A. rhizogenes ATCC15834 infection. Gus expression in infected petioles (a); leaf (b); and callus clusters (c). 


\section{Effect of bacterial density on transformation efficiency}

Bacterial density and the development of bacteria directly affect the transformation efficiency (Rashid et al., 2010). In this study, a correlation between bacterial density and the expression of gus was found. After $20 \mathrm{~min}$ of dipping the callus clusters in the Agrobacterium suspension, the percentage of guspositive callus explants ranged from 25 to $61 \%$, and the highest one was scored at the $\mathrm{OD}_{600}$ of 0.5 (Fig. 3). Previous studies reported that the suitable bacterial density for gene transformation is specific for the crop species and the bacterial strains used. For examples, Wahyu et al. (2012) found that when using $A$. rhizogenes ATCC15834 at $\mathrm{OD}_{600}$ of 0.5 for hairy root induction of Lycopersicon esculentum Mill, an induction rate of $33-59 \%$ was observed whilst a rate of $70 \%$ was obtained in Pueraria phaseoloides at $\mathrm{OD}_{600}$ of 1.0 (Shi, Kintizios, 2003).

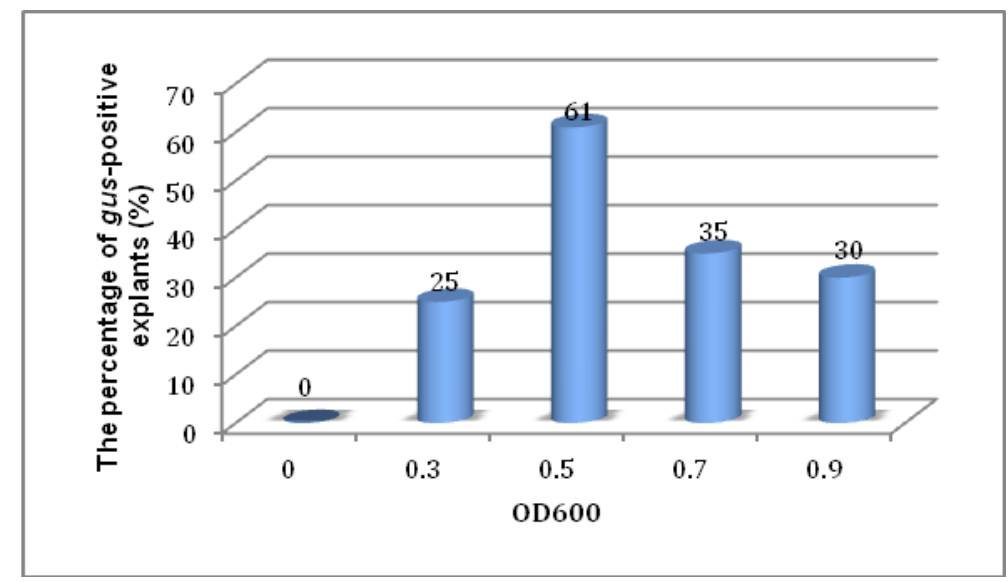

Figure 3. Effect of $A$. rhizogenes concentrations on transformation efficiency.

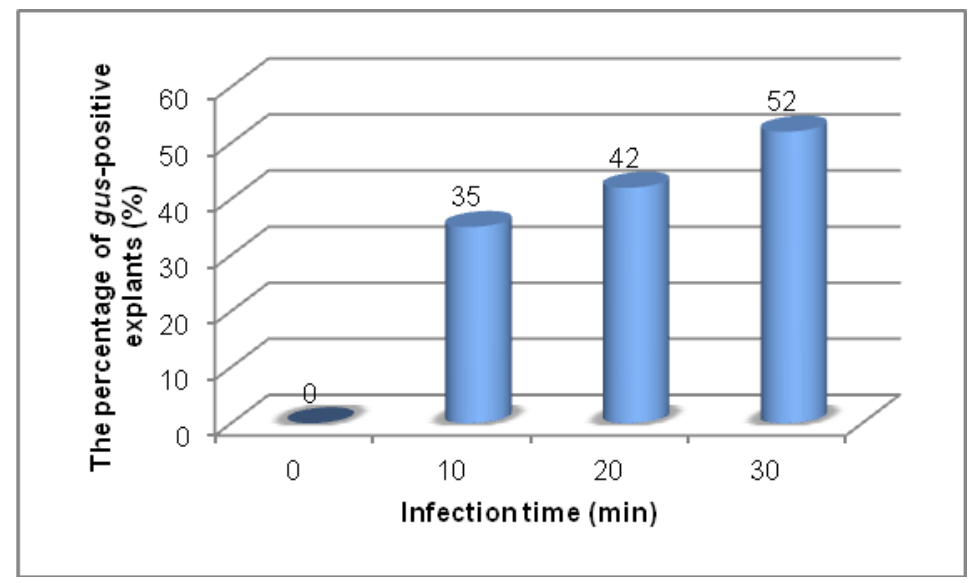

Figure 4. Effect of infection time on transformation efficiency.

Effect of infection time on transformation efficiency

Duration of infection time affects the transformation efficiency, survival and regeneration rates of explants. Increasing infection time directly affects the survival ability and development of plant tissues. The density of bacteria used during the infection process also influenced the development of bacteria during co-cultivation stage and elimination of bacteria. On the other hand, when using short time for bacterial infection, low bacterial density results in low transformation rate. 
In this study, there was a significant correlation between infection time and the percentage of guspositive explants (Fig. 4). However, longer time of infection caused necrotic explants (data not shown). Therefore, the time duration of 20 min was used for subsequent experiments.

In 2006, Tao, Li reported that 20 min was the optimal time duration for infection of $A$. rhizogenes in Torenia fournieri L. and obtained the best transformation efficiency as well as low necrosis rate.

\section{Effect of acetosyringone concentrations on gene transformation efficiency}

Acetosyringone (AS) acts as a chemotactic agent in very low concentrations and it activates the vir gene on the root inducing (Ri) plasmid, which initiates the infection process for the transfer of T-DNA (Huang et al., 2001). In the present study, $1 / 2 \mathrm{SH}$ medium supplemented with $100 \mu \mathrm{M}$ acetosyringone gave the highest percentage of gus-positive explants (59\%) compared with media with 50,150 , or $200 \mu \mathrm{M}$ AS or AS-free medium (control) (Fig. 5). The results suggested that high concentrations of AS were not effective for infection efficiency.

After culturing 8 weeks on medium with antibiotic, hairy root formation was recorded. Hairy roots were excised from transformed callus clusters and subsequently cultured on $\mathrm{SH}$ medium supplymented with $30 \mathrm{~g} / \mathrm{l}$ sucrose, $500 \mathrm{mg} / \mathrm{l}$ cefotaxime.

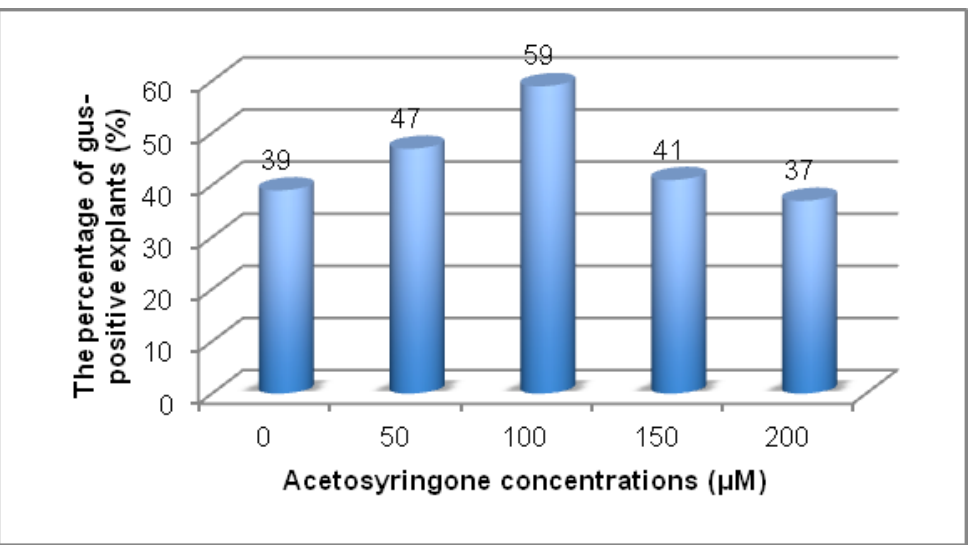

Figure 5 Effect of Acetosyringone concentrations on gene transformation.

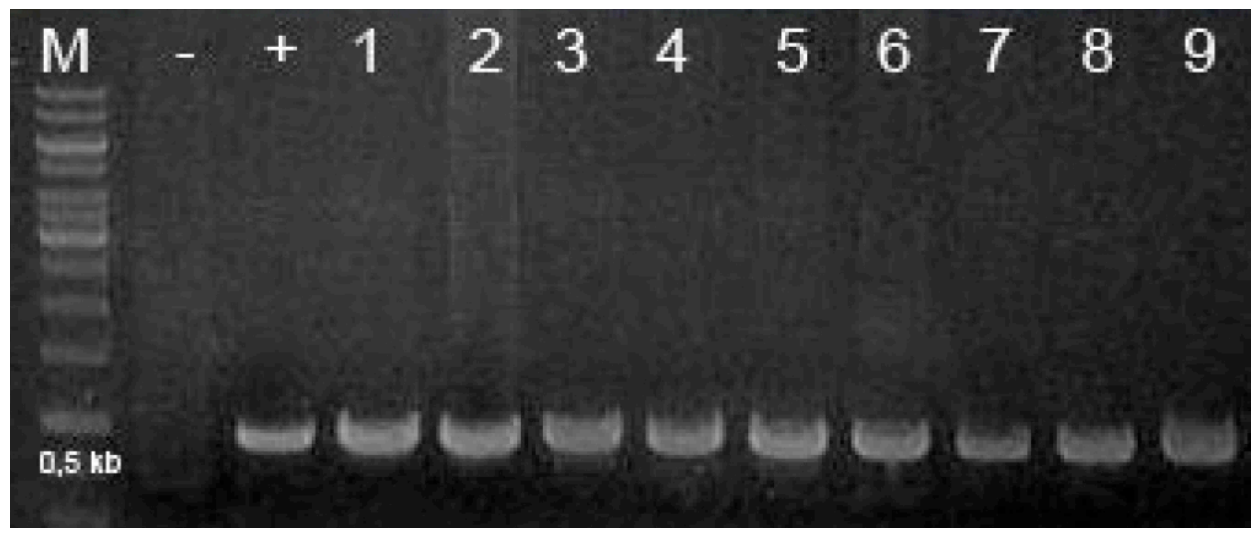

Figure 6. PCR analysis of the ro/C gene in the $P$. vietnamensis transformed roots. (-) negative control (PCR mixture without plant DNA); (+) positive control; (1-9) transformed hairy root samples.

\section{PCR amplification for checking T-DNA integration into the genome}

The rolC gene of $A$. rhizogenes T-DNA plays an important role in the formation of hairy roots (Gorpenchenko et al., 2006). In order to examine the integration of T-DNA into the genome of $P$. vietnamensis hairy root clones, total DNA extracted 
of root clones were used as templates for PCR amplifying rolC gene). It was clear that all root clones represent rolC gene bands that are approximately $0.6 \mathrm{~kb}$, similar to positive control band as shown in fig. 6 . The presence of rolC gene in the samples proved that the transgenic cultures were actually transformed with rol genes.

\section{Morphological variability among hairy root clones}

Morphological differences have been observed among hairy root clones in various plant sources (Wang et al., 2001). These differences might be caused by the non-specific integration of T-DNA into the host genome. The number of T-DNA copies and the integrative position of each transgenic clone are different. If the T-DNA is inserted into the active transcription regions, the expression of T-DNA may be much better than that of inactive transcription regions (Ngoc et al., 2012). In this study, the hairy root clones showed four different phenotypes such as roots that displayed the characteristic trait of hairy root with primary roots and some long lateral root branching (HR1) (Fig. 7a); roots that produced considerable lateral roots on primary roots (HR2) (Fig. 7b); roots that showed callus like phenotype with thick and short primary and lateral roots (HR3) (Fig. 7c) and roots which formed root clusters containing numerous short, thick root tips (HR4) (Fig. 7d).

These results are similar with those of Mallol et al. (2001) who described three morphological phenotypes observed when infected $P$. ginseng explants with $A$. rhizogenes strain A4 - an agropine-type similar to ATCC15834. When cultured on phytohormone-free SH medium, HR1 did not induced new root tips and had only primary or initial root tips developed without branching. Meanwhile, HR3 which formed callus-like phenotypes hardly developed hairy roots, and that the number and the length of root tips grew extremely slowly even after prolonged period of culturing on phytohormone-free $\mathrm{SH}$ medium. Similarly, HR4 also developed slowly in phytohormone-free SH medium. After 3 - 4 weeks, roots in the callus clusters began to elongate, but the number of clusters remained unchanged. In contrast, HR2 phenotype roots displayed the most rapid growth kinetic (Fig. 8). For example, after transfer to new media for one to two weeks, HR2 roots regenerated new lateral roots that elongated rapidly and exhibited prolific branching.

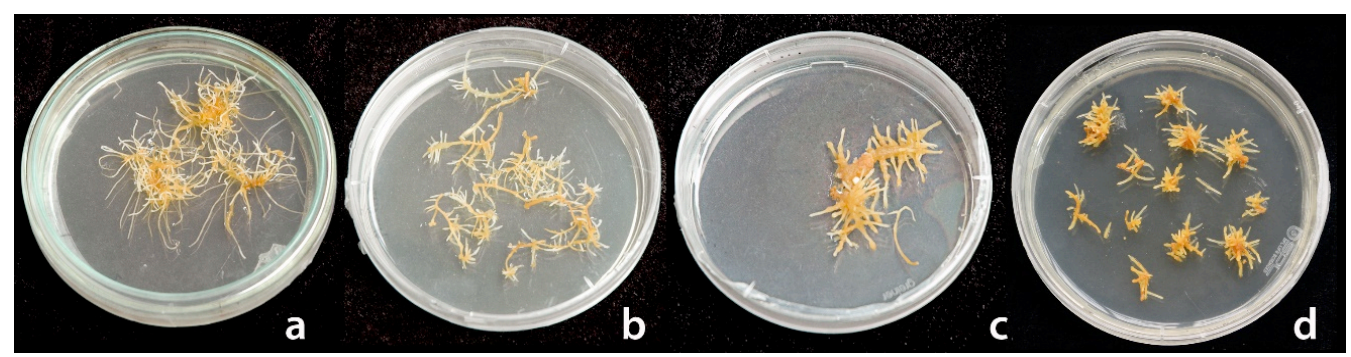

Figure 7. P. vietnamensis hairy root morphologies. a; b; c; d: HR1, HR2, HR3, HR4 phenotypes.
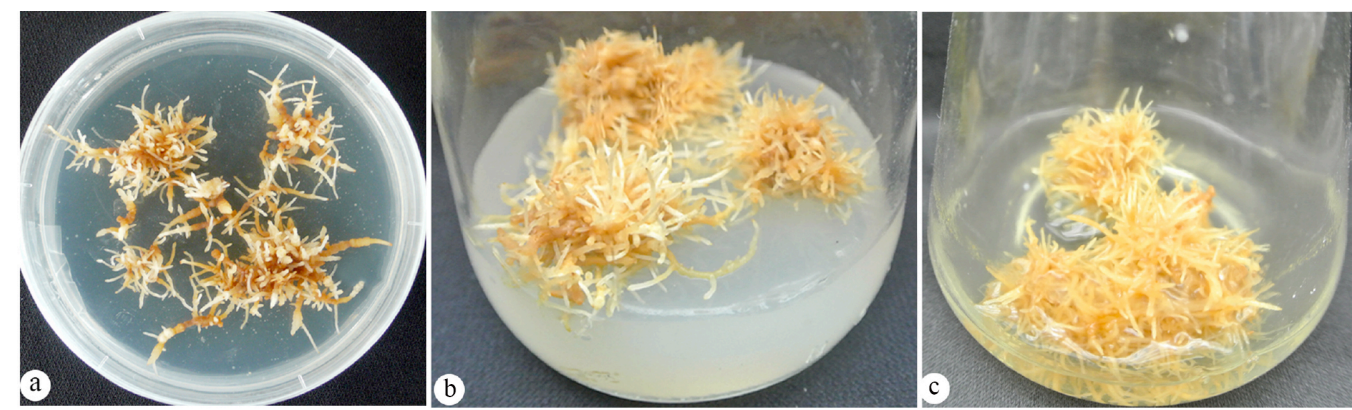

Figure 8. The growth of HR1 on solid medium after 8 weeks (a); 24 weeks (b) and liquid shaking medium after 12 weeks (c). 


\section{Estimate oncogenes expression through Real time PCR}

Real time PCR has become a key technique to measure changes in expression of target genes due to its accuracy, sensitivity and reproducibility. The expression of target genes in different conditions treatment is estimated using references genes that constitutively express in every tissue. Actin gene is commonly used as a reference gene for estimating gene expression in plants. The transcription level of target and reference genes are calculated based on the determination of fluorescence signal in real time PCR system. In this study, the expressions of oncogenes $($ rol $\mathrm{B}$, aux 1$)$ are quantified via actin gene using $2^{-\mathrm{ddCt}}$ calculating method.
It is evident that there was a relevant correlation between development ability and transgene expression in hairy root phenotypes. For instance, HR3 phenotype developed slowest and had the lowest gene expression in both rolB and aux 1 gene. Meanwhile, HR2 phenotype that proliferated outstandingly among the various root morphologies showed the highest rolB and aux1 expression, 8.72 and 5.52 times compared to HR3 (Fig. 9). The transgene expression in HR2 was almost double than that of HR4 and approximately four times HR1 (Fig. 9). Overall, rolB and aux 1 play an important role in hairy roots formation and development. In this study, the increase in rolB expression coincided with the rise of hairy roots growth ability.

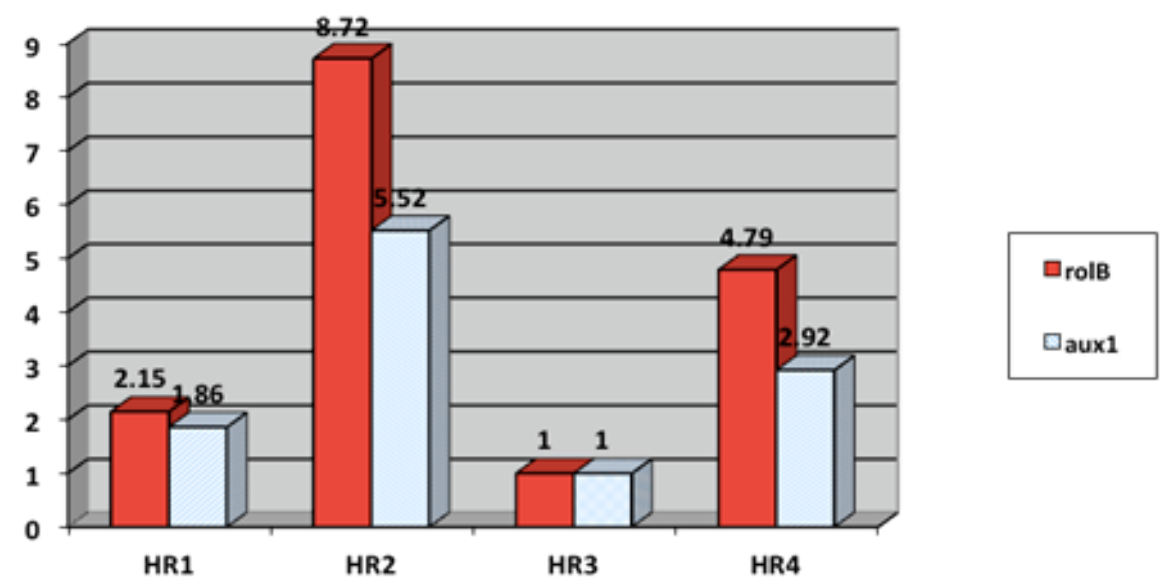

Figure 9. Oncogenes expression level in HR1, HR2, HR3 and HR4.
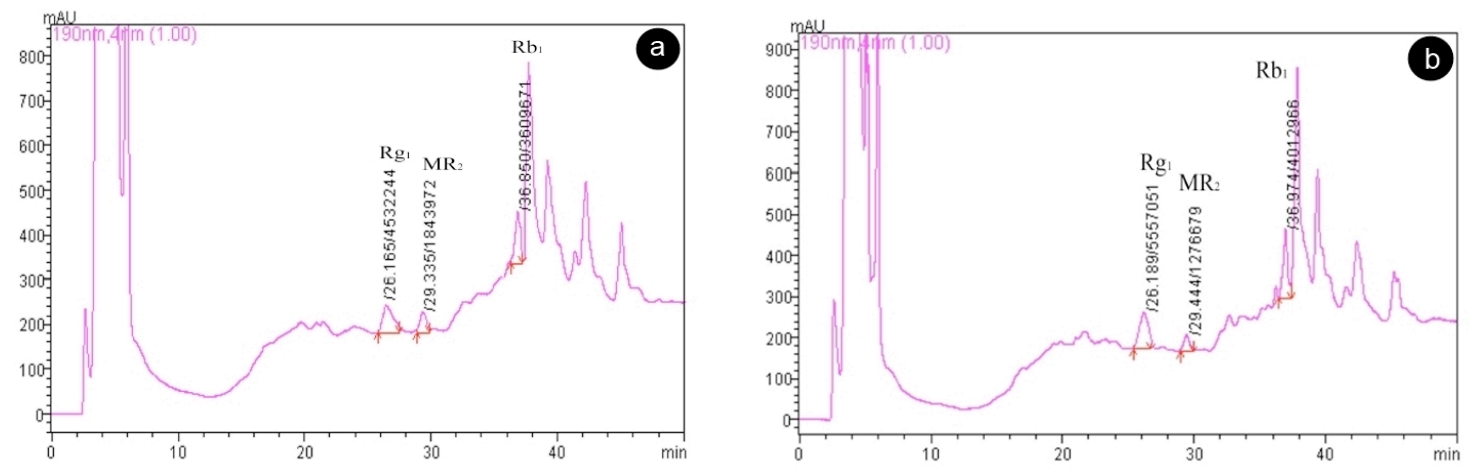

Figure 10. Diagram of the basic components of secondary metabolites of (a) P. vietnamensis in vitro rhizomes (control); and (b) transformed roots.

\section{Saponin analysis}

Saponin accumulation of transformed hairy roots and rhizomes of in vitro $P$. vietnamensis is shown in
HPLC diagram (Fig. 10). $\mathrm{Rg}_{1}, \mathrm{Rb}_{1}$ and $\mathrm{MR}_{2}$ were detected at the $26^{\text {th }}, 30^{\text {th }}$ and $37^{\text {th }}$ minutes, respectively (Fig. 10). These results indicated that there were no significant differences between the 
number of ginsenosides of transformed hairy roots of $P$. vietnamensis and that of the in vitro rhizomes.

\section{CONCLUSION}

In conclusion, we have successfully established a procedure for $A$. rhizogenes-mediated transformation of $P$. vietnamensis. Other factors affecting the hairy root induction and the transformation efficiency were also investigated. The protocol described in this study is simple and rapid and therefore, can be used for large-scale experiments for the rapid production of valuable compounds.

Acknowledgements: This work was financially supported by Ministry of Agriculture and Rural Development (Vietnam).

\section{REFERENCES}

Britton MT, Escobar MA, Dandekar AM (2008) The oncogenes of Agrobacterium tumefaciens and Agrobacterium rhizogenes. In: Tzfira T, Citovsky V, eds. Agrobacterium: from biology to biotechnology. New York, Springer, pp 523-563.

Chilton MD, Tepfer DA, Petit A, David C, Casse-Delbart F, Tempe J (1982) Agrobacterium rhizogenes inserts TDNA into the genome of the host plant root cells. Nature 295: 432-434.

Duc NM, Kasai R, Nham NT, Yamasaki K, Tanaka O (1997) Saponin composition of Vietnamese ginseng and its significance from pharmacognostical points of view. Proceedings of the first Indochina conference on pharmaceutical sciences: Pharmacy in harmony. Bangkok, Thailand: 273.

Duc NM, Kasai R, Ohtani K, Ito A, Nguyen TN, Yamasaki K, Tanaka O (1994) Saponins from Vietnamese ginseng (Panax vietnamensis Ha et Grushv.) collected in central Vietnam. Chem Pharm Bull, Tokyo 42(1): 115-122.

Georgiev MI, Pavlov AI, Bley T (2007) Hairy root type plant in vitro systems as sources of bioactive substances. Appl Microbiol Biotechnol 74: 1175-1185.

Giri A, Banerjee S, Ahuja PS, Giri CC (1997) Production of hairy roots in Aconitum heterophyllum Wall using Agrobacterium rhizogenes. In Vitro Cell Dev Biol Plant 33(4): 280-294.

Giri A, Ravindra ST, Dhingra V, Narasu ML (2001) Influence of different strains of Agrobacerium rhizogenes in induction of hairy roots and artemisinin production in Artemisia annua. Curr Sci 81: 378-382.
Gorpenchenko TY, Kiselev KV, Bulgakov VP, Tchernoded GK, Bragina EA, Khodakovskaya MV, Koren OG, Batygina TB, Zhuravlev YN (2006) The Agrobacterium rhizogenes rolC gene-induced somatic embryogenesis and shoot organogenesis in Panax ginseng transformed calluses. Planta 223: 457-467.

Guillon S, Tremouillaux-Guiller J, Pati PK, Rideau M, Gantet P (2006) Harnessing the potential of hairy roots: dawn of a new era. Trends Biotechnol 24: 403-409.

Hooykaas PJJ, Shilperoort RA (1992) Agrobacterium and plant genetic engineering. Plant Mol Biol 19: 15-38.

Huang JQ, Wei ZM, An H Zhu YX (2001) Agrobacterium tumefacien mediated transformation of rice with the spider insecticidal gene conferring resistance to leaf folder and striped stem borer. Cell Res 11: 149-155.

Ionkova I, Kartnig T, Alfermann W (1997) Cycloartane saponin production in hairy root cultures of Astragalus mongholicus. Phytochemistry 45(8): 1597-1600.

Jefferson RA (1987) Gus fusions: $\beta$-glucuronidase as a sensitive and versatile gene fusion marker in higher plants. EMBO J 16: 2901-2907.

Khanuja SPS, Shasany AK, Darokar MP, Kumar S (1999) Rapid isolation of DNA from dry and fresh samples of plants producing large amounts of secondary metabolites and essential oils. Plant Mol Biol Rep 17: 1-7.

Mallol A, Cusidó RM, Palazón J, Bonfill M, Morales C, Piñol MT (2001) Ginsenoside production in different phenotypes of Panax ginseng transformed roots. Phytochemistry 57(3): 365-371.

Murashige T, Skoog F (1962) A revised medium for rapid growth and bioassay with tobacco tissue culture. Physiol Plantarum 15: 473-497.

Ngoc PB, Trong ND, Ha H, Nhan LD, Ha CH (2012) Agrobacterium rhizogenes mediated hairy root formation in Ba Benh (Eurycoma longifolia Jack). J Sci Technol 50(3B): 166-173.

Nilsson O, Moritz T, Sundberg B, Sandberg G, Olsson O (1996) Expression of the Agrobacterium rhizogenes rolC gene in a deciduous forest tree alters growth and development and leads to stem fasciation. Plant Physiol 112: 493-502.

Nhut DT, Hai NT, Huy NP, Chien HX, Nam NB (2013) New Achievement in Panax vietnamensis Research. In Jain SM and Gupta SD, eds. Biotechnology of Neglected and Underutilized Crops, Springer Science Business Media, Dordrecht, 43-57.

Nhut DT, Luan VQ, Binh NV, Phong PT, Huy BN, Ha DTN, Tam PQ, Nam NB, Hien VT, Vinh BT, Hang LTM, Ngoc DTM, Thao LB, Luan TC (2012) The effects of some factors on in vitro biomass production of Vietnamese ginseng (Panax vietnamensis Ha et Grushv.) and 
preliminary analysis of saponin content. $J$ Biotech 7 (3): $357-370$.

Piqueras A, Alburquerque N, Folta KM (2010) Explants Used for the Generation of Transgenic Plants. In Kole C, Michler CH, Abbott AG, Hall TC, eds. Transgenic Crop Plants, Springer-Verlag Berlin Heidelberg.

Rashid H, Afzal A, Khan MH, Chaudhry Z, Malik SA (2010) Effect of bacterial culture density and acetosyringone concentration on Agrobacterium mediated transformation in wheat. Pakistan J Bot 42(6): 4183-4189.

Schenk RU, Hildebrandt AC (1972) Medium and techniques for induction and growth of monocotyledonous and dicotyledonous plant cell cultures. Can J Bot 50: 199204.

Shanks JV, Morgan J (1999) Plant hairy root culture. Curr Opin Biotechnol 10: 151-155.

Shi HP, Kintizios S (2003) Genetic transformation of Pueraria phaseoloides with Agrobacterium rhizogenes and puerarin production in hairy roots. Plant Cell Rep 21(11): 1103-1107.
Tao J, Li L (2006) Genetic transformation of Torenia fournieri L. mediated by Agrobacterium rhizogenes. $S$ Afr $J$ Bot 72(2): 211-216.

Vanhala L, Hiltunen R, Oksman-Caldentey KM (1995) Virulence of different Agrobacterium strains on hairy root formation of Hyoscyamus muticus. Plant Cell Reports 14: 236-240.

Wahyu W, Ratna P, Estri LA, Edi PU, Tatik W (2012) Genetic transformation of tomato (Lycopersicon esculentum Mill.) with Agrobacterium rhizogenes and production of lycopene in transformed root culture. $J$ Int Biotech Res 3(9): 158-165.

Wang YM, Jiang Bo WANG, Da LUO, Jing Fen JIA (2001) Regeneration of plants from callus cultures of roots induced by Agrobacterium rhizogenes on Alhagi pseudoalhagi. Cell Research 11: 279-284.

Zhai WM, Yuan YS, Zhou YX, Wei L (2001) HPLC Fingerprints Identification of $P$. ginseng C. A. Mey., $P$. quinquefolin L. and P. notoginseng (Burk. F. H. Chen). Chi J Chi Mater Med 26(7): 481-482.

\title{
CHUYỀn GEN QUA TRUNG GIAN VI KHUÂN AGROBACTERIUM Ở CÂY SÂM NGỌC LINH (PANAX VIETNAMENSIS HA ET GRUSHV.)
}

\author{
Dương Tấn Nhựt ${ }^{1}$, Nguyễn Phúc Huy ${ }^{1}$, Trịnh Thị Hương ${ }^{1,2}$, Vũ Quốc Luận ${ }^{1}$, Vũ Thị Hiền ${ }^{1}$, \\ Hoàng Thanh Tùng ${ }^{1}$, Đỗ Mạnh Cường ${ }^{1}$, Chu Thị Bích Phượng ${ }^{1}$, Phạm Bích Ngọc $^{3}$, \\ Nguyễn Đình Trọng ${ }^{3}$, Nguyễn Khắc $\mathrm{Hưng}^{3}$, Chu Hoàng $\mathrm{Hà}^{3}$ \\ ${ }^{1}$ Viện Nghiên cưu Khoa học Tây Nguyên, Viện Hàn lâm Khoa học và Công nghệ Việt Nam \\ ${ }^{2}$ Đại hoc Công nghiệp Thực phẩm Thành phố Hồ Chí Minh \\ ${ }^{3}$ Viện Công nghệ Sinh học, Viện Hàn lâm Khoa học và Công nghệ Việt Nam
}

\section{TÓM TẮT}

Trong những năm gần đây, chuyển gen qua trung gian vi khuẩn Agrobacterium đã được sử dụng rộng rãi để đưa gen ngoại lai vào tế bào thực vật và sau đó tái sinh thành các cây biến đổi di truyền. Sâm Ngọc Linh là cây thuốc có giá trị cao của Việt Nam nhưng diện tích phân bố của loài này bị giới hạn. Nghiên cứu này trình bày quy trình chuyển gen thu nhận rễ tơ sâm Ngọc Linh, tạo nguồn nguyên liệu cho nuôi cấy sinh khối thu nhận saponin một cách hiệu quả. Trong nghiên cứu này, mẫu lá (có diện tích $0,5 \mathrm{~cm}^{2}$ ), cuống lá (dài $1 \mathrm{~cm}$ ) và cụm mô sẹo (thể tích $0,5 \mathrm{~cm}^{3}$ ) được sử dụng để chuyển gen cảm ứng tạo rễ tơ. Kết quả thu được cho thấy, rễ tơ sâm Ngọc Linh được cảm ứng từ việc lây nhiễm mô sẹo với vi khuẩn Agrobacterium rhizogenes chủng ATCC15834 ở $\mathrm{OD}_{600}=0,5$ với thời gian lây nhiễm là 20 phút và có bổ sung $100 \mu \mathrm{M}$ acetosyringon. $\mathrm{PCR}$ được sử dụng để kiểm tra sự hiện diện của gen rol. So sánh với rễ sâm Ngọc Linh nuôi cấy in vitro cho thấy, rễ tơ có tiềm năng sản xuất liên tục các chất chuyển hóa thứ cấp và có lượng saponin tương tự với rễ nuôi cấy in vitro. Quy trình chuyển gen thu nhận rễ tơ sâm Ngọc Linh mô tả trong nghiên cứu này đơn giản và nhanh chóng, do đó có thể được sử dụng cho quy mô lớn để sản xuất nhanh các hợp chất thứ cấp có giá trị.

Từ khoá: Agrobacterium rhizogenes, chuyển gen, rễ to', saponin, sâm Ngọ Linh 